\title{
An integrated leadership model for leading Education for Sustainability in Higher Education and the vital role of students as change agents
}

Warwick, Paul

http://hdl.handle.net/10026.1/5101

10.1177/0892020616653463

Management in Education

SAGE Publications

All content in PEARL is protected by copyright law. Author manuscripts are made available in accordance with publisher policies. Please cite only the published version using the details provided on the item record or document. In the absence of an open licence (e.g. Creative Commons), permissions for further reuse of content should be sought from the publisher or author. 


\title{
An integrated leadership model for leading Education for Sustainability in Higher Education and the vital role of students as change agents
}

\author{
Paul Warwick
}

Plymouth University, UK.

\begin{abstract}
This paper explores the leadership of Education for Sustainability (EfS) within Higher Education (HE), focusing specifically on the key role students can play as internal catalysts for change. It presents a case study of Plymouth University, a higher education institution (HEI) with an international reputation for EfS leadership. The paper outlines the importance of seeking cultural transformation in the leadership of sustainability, highlighting the benefits of an integrated approach that encompasses teaching and learning, research, and campus and operations. This manifold and coordinated approach requires top down strategic support in order for EfS to take root and gather momentum. However, in this paper it is argued that the bottom up empowerment of 'students as change agents' is just as vital. Reflecting on the strengths and weaknesses of a number of student leadership initiatives at Plymouth University, this paper argues that EfS reform in HE has significant implications for staff training and the design of participatory learning spaces in order for students to have their voices heard and to be partnered with as leaders.
\end{abstract}

\section{Introduction}

Debate rages over appropriate forms of Higher Education in the $21^{\text {st }}$ Century. From the standpoint of sustainability, the multiple points of crisis that our students are growing up in the midst of requires a radical rethink of what we mean by 'graduateness' and the experiences of HE that dominate our students' lifeworlds. This paper focuses upon Plymouth University in the UK, an institution that has attempted to frame notions of quality HE through the lens of sustainability. This institution's trajectory of Education for Sustainability (EfS) leadership has led to recent moves to raise the profile of students not as mere consumers of this educational reform, but partners in the innovation process. Pursuing an integrated model of leadership in education has required greater attention to how students can be engaged as 'critical creatives' with a unique insight into current sustainability educational provision and a collaborative capacity to invent new learning spaces.

\section{Education for Sustainability - framing a catalytic starting point}

The foundational aspect in the leadership of EfS at an institutional level has been to frame this call for educational reform, to both staff and students, in a way that sparks interest and engagement across disciplinary boundaries. In recent guidance to the HE sector in the UK, the Quality Assurance Agency for Higher Education and the Higher Education Academy define EfS as:

...the process of equipping students with the knowledge and understanding, skills and attributes needed to work and live in a way that safeguards environmental, 
social and economic wellbeing, both in the present and for future generations.

(QAA 2014:5)

Importantly, this guidance document gives attention to the pedagogy of EfS, the how of teaching and learning, as well as the content and the what of the curriculum. It frames the holistic agenda of EfS recognising, in a matrix of thirty-eight graduate outcomes, the need to draw out specific attributes and skills, alongside knowledge and understanding.

This holistic framing of EfS is echoed by the model of Education for Sustainable Development that is currently being applied at Plymouth University.

As shown in Figure 1 this theoretical representation of EfS, highlights a set of holistic relational and pedagogical dimensions that stem from the value base of an active concern for well-being:

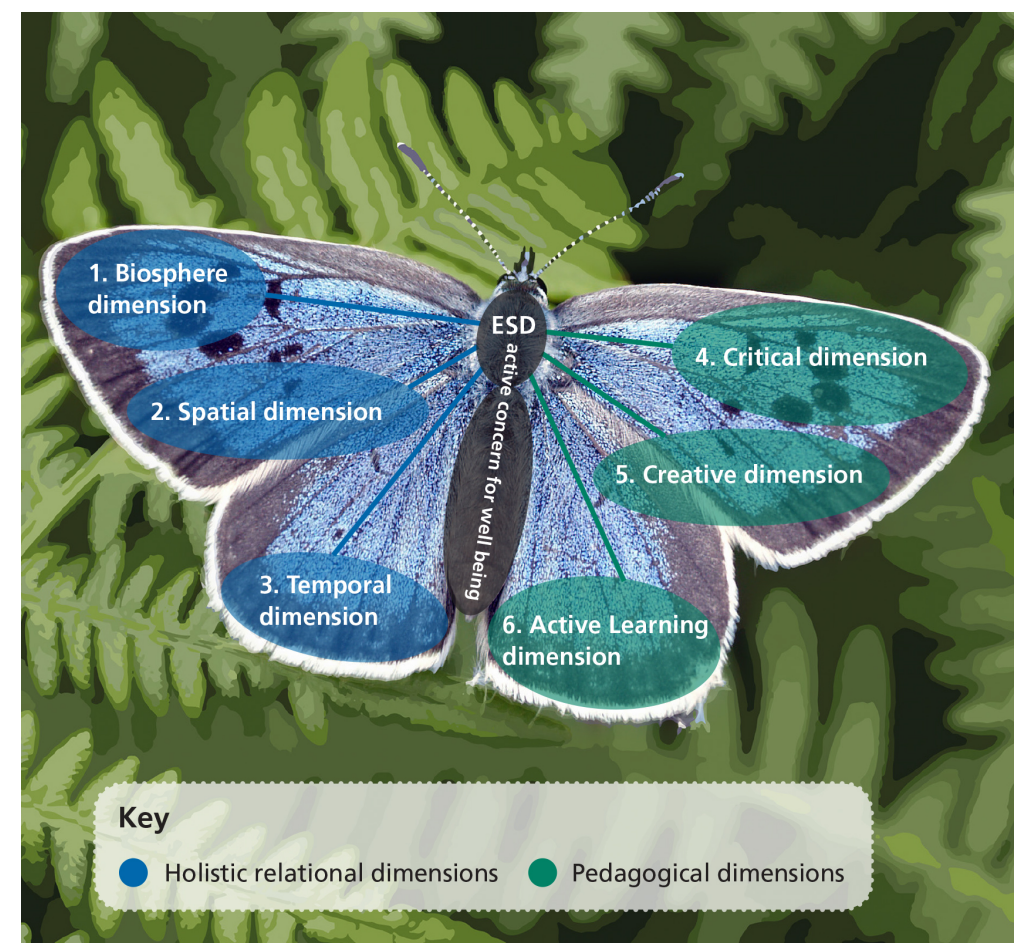

Figure 1 The Education for Sustainable Development Butterfly Model Source Peterson and Warwick (2015: 133)

This model of EfS firstly acknowledges a paradigm of education oriented by the centrality of extrinsic values such as care and compassion for the common good. The United Nations Economic Commission for Europe (UNECE 2012:6) frames EfS as being underpinned by 'an ethic of solidarity, equality and mutual respect'. At the heart of EfS is explicit attention to learners being energised and enthused by exploring the ethical stance of holding an active concern for well-being and stretching their compassionate consideration across three relational dimensions:

1. The biosphere dimension

Concern for the common good encompassing people and planet

This relational dimension goes beyond anthropocentric considerations and seeks to draw out from learners the capacity to critically consider both human and 
environmental well-being. It acknowledges that human problems and ecological problems are inextricably intertwined and need to be understood in relation to each other. This raises the importance of a $21^{\text {st }}$ Century higher educational system that nurtures new forms of sustainability literacy that go beyond the political, social and economic. As Stone (2009: 4) suggests:

This generation will require leaders and citizens who can think ecologically, understand the interconnectedness of human and natural systems and have the will, ability and courage to act.

\section{The spatial dimension}

Concern for the common good spanning across place; from local to global. This dimension of EfS involves learners considering their local, national and global interdependency. It seeks to raise awareness of how, through environmental processes coupled with global processes of communication, industrialisation and commerce, our lives today are caught up in a network of mutuality that goes beyond local neighbourhoods and nation states. This dimension recognises the interconnectivity of life across place and landscape and invites learners to consider their personal links to worldwide issues of peace, justice, rights, inclusion and environmental stewardship.

\section{The temporal dimension}

Concern for the common good stretching across time; from present to future This dimension involves a consideration of the interconnectivity of life across time and the links that exist between the past, present and future. It encourages examination of the historical roots of the sustainability challenges we currently face as well as consideration of the implications of our lifestyles on future generations and landscapes. It advocates the development of more long term views within policy, civic engagement and lifestyle decision-making processes.

From this expanded consideration of an active concern for the common good that highlights relational interconnectivity across species, place and time, the butterfly model of EfS proposes pedagogical processes that are deemed congruent to achieving these educational objectives. Three key dimensions of this pedagogy being:

\section{The critical dimension}

\section{Space for dialogue and systems thinking}

This first of the pedagogical dimensions presents the need for dialogic learning opportunities where sustainability issues can be critically considered through engagement with multiple perspectives. This dimension gives greater emphasis to interdisciplinary learning and systems-thinking approaches (Morris and Martin, 2009; Sterling, 2005; Stone and Barlow, 2005). This is to help learners understand the dynamic and interconnected nature of sustainability challenges and to develop the capacity to navigate the risks and unpredictable consequences of these challenges as they unfold. Within this dimension the aim is not simply to raise sustainability literacy through awareness of 'other perspectives,' but to also provide consciousness raising opportunities for reflexivity, where individuals consider their own perspectives, assumptions and the implications of civic and lifestyle choices. As identified by Vare and Scott (2007), this critical dimension ensures that EfS is not simply about the unproblematic transmission or promotion of certain sustainable behaviours. 


\section{The creative dimension}

\section{Space to imagine new sustainable futures}

This dimension supports a re-conception of the importance of education nurturing learners' creative capacities. It holds as being of fundamental importance the need to encourage learners in the process of generating and exploring what Robinson (2011) refers to as 'original ideas that are of value'. This is based upon the view that all citizens have the potential to play a vital role in creating sustainable futures. Whilst educators can share useful insights into current sustainable policies and practices, it is impossible for them to foresee entirely how global challenges are going to play out in the lifetimes of their students. EfS therefore seeks to provide creative learning spaces that give explicit attention to drawing out from learners the ability to collaboratively problem solve, imagine new ways of being and successfully navigate unpredictable change events.

\section{The active learning dimension}

Space to collaboratively act in pursuit of sustainability

This pedagogical dimension recognises the potential of both staff and students serving as 'compassionate critical creatives', experientially learning through the process of putting their ideas for preferable futures into action. Whilst a wide variety of educational approaches can be utilised within EfS, emphasis needs to be given to providing the collaborative and intergenerational learning space where people are able to gather together and actively explore sustainability challenges. In her review of EfS learning processes for the United Nations Decade of Education for Sustainable Development (UNDESD), Tilbury (2011) cites over 20 studies from scholars worldwide that highlight the alignment of EfS with active and participatory approaches. Through the active learning process of conceptualising, planning, acting and reflecting, students are better able to engage holistically with the values, skills and knowledge areas of sustainable development.

Notions of sustainability and EfS remain contested and complex. The key objective in the leadership of EfS at an institutional level is not to mask this contested nature, but to provide a framing narrative that serves as a catalytic starting point. The butterfly model of EfS, presented above, succeeds or fails by its ability to hook stakeholders' interest from across the disciplines. It seeks to invite all into a dialogic space for engaging with EfS leadership. From this starting point, an interdisciplinary community of inquiry has the possibility to emerge, but a conducive institutional context is essential in order for EfS practice to take root and become established.

\section{Plymouth's pursuit of a conducive institutional environment for the integrated leadership of EfS}

The UK's Plymouth University is working toward a comprehensive integration of sustainability practice and teaching... with a strong focus on sustainability since 2005. Clugston and Calder (2014:123).

Plymouth is widely recognised as a pioneer in the HE sector through re-orienting its policy and practice towards sustainability. Having begun the work some years before, 
in 2005 the University was awarded funding by the Higher Education Funding Council for England (HEFCE) to establish a Centre for Excellence in Teaching and Learning in EfS. Titled the Centre for Sustainable Futures (CSF), it began a programme of systemic change and support, developing an integrated model of whole institutional change, see Figure 2.

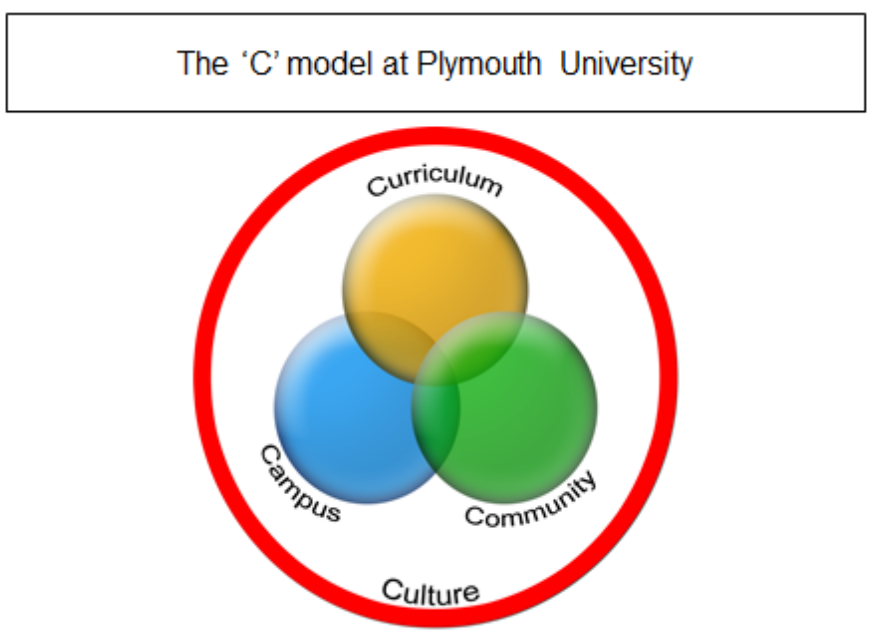

Figure 2 A whole institutional approach to EfS leadership (Sterling 2015:3)

This approach identified four key interconnected spheres within which sustainability needed to be developed, the campus, curriculum, community and ultimately the whole institutional culture. This $4 \mathrm{cs}$ model of change leadership has since been adopted by many other HEIs.

Led by pioneers in the EfS field, including Alan Dyer, David Selby and Stephen Sterling, this approach resulted in Plymouth University adopting sustainability as one of its key corporate ambitions and the development of one of the first whole institutional sustainability strategies in the sector.

With the 'permission' of this top down strategic mandate, CSF has been able to coordinate a manifold range of EfS leadership activities. This has included working collaboratively with over 100 staff from across all schools and faculties on the development of new modules and programmes, pedagogic research and professional development. In recent years the leadership structures have diversified and expanded with new units being formed to focus specifically on the co-ordination of sustainability research and the systematic development of the sustainable campus, overseen by a University Sustainability Advisory Group (SAG). The SAG ensures that various sustainability action points across the institution remain co-ordinated and interlinked.

As a result Plymouth University has played a distinctive role in supporting the development of EfS across the sector. It has produced a range of resources and publications that have influenced policy and practice in other HEIs both nationally and internationally. These include a guidebook to introducing sustainability into teaching and learning commissioned by the HEA (Sterling 2012); and a book outlining the progress of ten UK universities, including Plymouth, towards the more sustainable university (Sterling et al 2013). 


\section{The missing link - recognising students as internal agents of educational change}

In its most recent strategic leadership of EfS, Plymouth University has recognised the need for greater student engagement. An integrated EfS leadership approach needs to continually embrace students themselves as partners in the endeavour. This aspect of an institution wide collaborative approach to leadership has been advanced in a number of ways, two of which are considered in greater depth here to highlight key lessons.

\section{Case Study 1 Harnessing student voice within module improvement processes}

One 'students as partners' initiative at Plymouth University has been to systematically capture students' experiences of new EfS undergraduate modules in order to help staff identify areas for future improvement. An example of this approach being applied is within a pioneering undergraduate EfS module run by the Plymouth Business School.

This second year optional module was designed to be interdisciplinary in content and participatory in process. Learning sessions were organized into themed clusters and taught by a team of staff; enabling students to look at the concept of sustainability in organisations through a range of lenses including accounting and finance, economics, marketing, business management, organisational development and entrepreneurship. It also sought to offer a deliberative and active pedagogy, with each themed cluster offering opportunities for student discussion, world cafés, problem based learning, collaborative group work and independent study.

On paper, the course exemplifies what international EfS pedagogical research is advocating, but what were the students' experiences? Could data collection techniques designed to gather students' perspectives on their lived experiences of the module provide an important insight into where further improvements were needed? This was explored using a broad participatory action research strategy (Kemmis and McTaggart 2005) that also drew from lesson study as a form of professional learning. As described by Dudley (2014), lesson study is specifically concerned with collecting data that focus on students' learning rather than on teacher's teaching, whereby the deeper understanding of students' experiences contributes to the leadership of a continuously refined pedagogy. This empathetic approach to educational improvement is very much in contrast with top-down lesson dipping approaches to teacher development that currently dominate within formal educational systems (Puchner \& Taylor, 2006). Such a small scaled qualitative research project is not without its limitations in its capacity to shed light on the complex phenomenon of an educational module and in its attempt to capture and construct meaning from students' consciousness and interpretations of their specific pedagogical experiences (Pring 2000). At best it is an example of partnering with students in the leadership of EfS that can lay claim to having gained a deeper insight into aspects of the reality of this module. But this is what the study attempted by integrating and overlapping different data collection methods including observations, student focus groups, a student evaluation workshop and staff and student one to one semi structured interviews. Collecting data from a cohort of 52 students and seven teaching staff revealed a number of insights into students' experiences of this particular EfS module including: 
- Comparatively the students feel there is something qualitatively different about this module due to its collaborative and personalised learning opportunities:

"Feels refreshing to learn from other students rather than just being told what is right or wrong by a lecturer."

"Out of my six modules this year, this is the one I've learnt the most on because it's more for what you want to do rather than you've got to learn this for exams."

- The dialogic nature of teaching is changing patterns of student engagement. The students participating in the research spoke of the deliberative and dialogic nature of the teaching session having significant impacts upon their learning:

"You don't necessarily realise that you're learning at the time, but then when you go away from it, you've got what you've subconsciously absorbed from the session. It's actually quite amazing compared to what I would have had if I had been taking notes. Because it would have been on the notes, not in my brain."

"I always refer back to that one lecture when we had the debate......and just the way [the facilitator] ran that by not talking and letting us carry on and I've just never been in a lecture like that before..... I think that's going to be like a lecture that you'll always remember throughout my life."

- For some, the course has been transformative._A number of participating students spoke of the module leading to far reaching changes in their perspectives on sustainability:

"Almost makes you feel contempt for current practices and norms and for the allowance for this wasteful practice to continue and progress so far. It has encouraged the pool of thought that it is through collective action rather than dependence on businesses/Government/organisations to change and that a cultural shift in regards to sustainability is imperative."

As well as capturing a range of appreciative viewpoints about this module, the student voice has crucially revealed areas for staff to consider in the leadership of future improvement. These include:

1. From the students' perspective, in the early stages of the module there is a need to provide more in the way of helping students to transition into this new interactive, collaborative and issue-based pedagogy. Students spoke of the need to provide explicit guidance on the learning processes this module was going to engage them with, such as problem-based learning and to provide study skills' development on key aspects such as guidance on note-making approaches suitable for dialogic engagement. This raises the importance of appropriate staff training in EfS to ensure the expert facilitation of active pedagogies and students transitioning into these potentially less familiar learning processes. 
2. Students called for the module's real world learning objectives requiring more real world learning spaces being provided. Future leadership of the module, students suggested, needed to make greater use of community partnerships and place-based learning, where students are able to learn through connection to and applied learning opportunities within local companies, social enterprise and charitable organisations that are seeking to apply sustainability practices.

3. Students experienced a critical tension between the course wanting to be interdisciplinary and also valuing student autonomy. They felt free to opt in and out of themed clusters of teaching depending upon their personal interests as the main assessment task allowed them to chose a specific disciplinary area of focus. Drawing from the students' perspectives, and the work of scholars such as Biggs and Tang (2007), there is a need in this module to constructively re-align the main assessment task in order to encourage and capture the intended interdisciplinary learning outcomes whilst still allowing for a degree of student freedom to choose specific areas for deeper exploration.

4. Students identified the need for help in perceiving threads of interconnectivity and synergy between the different themed clusters and different staff contributions in order to address experiences of the course feeling disjointed in its multi-disciplinary nature. This perspective advocates for an ever-present 'learning-facilitator', helping students to make the links between and flows across the different disciplinary areas. This raises institutional management issues around appropriate workload models and the allocation of sufficient staff time to enhance interdisciplinary educational provision.

This small-scaled action research project highlights the professional development opportunities that exist for EfS staff who seek to improve their teaching practice through conversational narratives with their students. It represents a pedagogical research approach that is based upon partnership between module teaching staff and their students in order to advance interdisciplinary, deliberative and active pedagogical approaches. In so doing the hope is that it represents a collaborative leadership approach that enables staff and students to join together and discover new ways to more effectively 'walk the talk' of EfS.

\section{Case Study 2 Developing Future Leaders}

Giving priority to engaging students as partners in creating new sustainability education opportunities is a key objective of Plymouth University's sustainability strategy. Towards this aim, in 2014 the CSF launched the Future Leaders Programme. This programme enables students to utilise their creativity and enterprising spirit by collaboratively leading their own EfS innovations.

The Future Leaders Programme draws from servant leadership models (Greenleaf 2002) and service learning pedagogies (Stanton et al 1990, Butin 2010) and seeks to engage students from across all disciplines and levels of HE study. The co-curricular positioning of the programme affords the space for leadership workshops to be based upon the interests, progress and experiences of the students rather than to be predetermined in content and timetable. This means the students' enthusiasm, questions, ideas and actions essentially guide the flightpath of the programme. In so doing, this 
EfS initiative is seeking to explore in a practical way a new learning space for students to develop what Wayman (2009:96) refers to as 'informed purposive action'. By engaging with students as 'compassionate critical creatives' they are supported in pursuing their preferred images of the future of sustainability education at Plymouth University. The applied nature of the programme is seeking to help students to develop the competencies, relationships and wisdom necessary for engaging with a sense of hope and efficacy around pressing sustainability challenges, whether that be at personal, community or institutional levels. In so doing, the Future Leaders Programme is also in tune with the recent Higher Education Academy's guidance on student engagement that recognises a range of different levels through which students can participate actively in shaping their own learning (Healey et al 2014).

The programme has led to students identifying a range of gaps and shortfalls in the University's current EfS practice and provided an invaluable insight into where their interest and passion for change resides. As a result the students have developed a range of EfS innovations including:

- Addressing the problem of student unawareness of the University's sustainability profile by transforming the way sustainability is introduced within induction week activities using a peer education approach that reached over 800 undergraduates in 2015

- Developing wild walk and sustainable bike ride opportunities for students - using outdoor learning approaches to help broaden students' horizons beyond the city centre and out into the countryside and coastline that surround the city

- Contributing to a greening the campus initiative that includes staff and students learning through gardening; growing food and increasing biodiversity on campus

- Addressing students' interest in waste reduction on campus by supporting the development of a Waste Electrical and Electronic Equipment (WEEE) recycling site.

- Creating interactive workshops that introduce sustainability to other students engaged in leadership roles across the university such as school course reps, student union elected executive officers and the leadership teams of clubs and societies

- Partnering with staff to create an annual one-week intensive co-curricular opportunity for students to explore the interface between sustainability and global citizenship

- Enabling students to have the opportunity to learn through community partnerships with cultural change organisations such as a language school helping to meet the needs of asylum seekers and refugees who arrive in the city

- The students have also created their own social media site for sharing sustainability education news, events and opinion pieces with peers, above and beyond the University's corporate sites.

This programme has highlighted the potential of students being change leaders; offering a fresh insight into where EfS issues of concern lay and how students can take the lead through collaborative leadership. Facilitation of this programme has highlighted the challenging skill set and relational dexterity that the role requires of staff and the need for considerable staff development and training to extend this type of learning space to more students across the institution. It has also highlighted the need for flexible learning spaces for such relational, student centred and community partnered EfS to flourish; calling for the design in HE of new learning spaces that are dynamic, engaged, ecological and participatory (Wood et al 2012). It has also 
revealed a potential weakness of this pedagogical approach with regard to the lack of continuation of many of the students' EfS innovations. Currently there is a risk of the students' creating mere bubble practices that are planted by a specific group of students and flourish for a season only to wither away when those students graduate and move on. The effective leadership of educational change needs to give careful attention to continuation aspects within the overall process (Fullan 2016) and this remains an area requiring further investigation within the Future Leaders Programme.

\section{Conclusion}

Radical changes are currently in motion with regard to the role and function of HEIs (Light et al 2009). At its best this reform is research informed by theoretical developments about how people learn and effective teaching practice (Illeris 2009). Strands of this reform are also informed by emerging theory and practice around educational institutions needing to address the challenge of enabling a 'world ready' citizenry who are informed and equipped for sustainable development in the $21^{\text {st }}$ Century.

The experiences of Plymouth University have shown that staff and students are enthused and engaged by a paradigm of educational change that is framed around the compassionate notion of better serving the common good. EfS provides an important opportunity of challenge and growth for students today. It invites them to develop both the competencies and social capital necessary for considering the well-being needs of people and the natural environment, from the local to the global, today and tomorrow. EfS is based upon the premise that not only can students help others in their pursuit of a quality of life, but that they themselves need the help of others pointing towards the interconnected nature of how all our lives are bound together.

A systems thinking approach has proved effective in developing a leadership strategy for EfS at an institutional level. It has highlighted the complexity and interconnected nature of seeking to change the culture of an institution and the integrity of the ambition to go through this process with staff and students as partners, rather than simply impose it upon them through a top down insistence. Plymouth University's journey has also highlighted the potential of students as agents of change - able to bring about innovation in EfS that is apt and vibrant and of their own making.

\section{References}

Biggs, J. \& Tang, C. (2007) Teaching for quality learning at university. Open University Press, Maidenhead.

Butin, D. (2010) Service-Learning in Theory and Practice: The Future of Community Engagement in Higher Education, New York: Palgrave Macmillan.

Clugston, R and Calder, W (2014) Higher education for strong sustainability, in Corcoran, P. B and Hollingshead, BP, (2014) Intergenerational Learning and Transformative Leadership for Sustainable Futures, Wageningen Academic Publishers, Wageningen. pp 113-126 
Dudley, P. (2014) Lesson Study: Professional learning for our time. Oxon: Routledge

Fullan, M. (2016) The new meaning of educational change (Fifth Edition). Oxon: Routledge.

Greenleaf, R (2002) Servant leadership: a journey into the nature of legitimate power and greatness. New Jersey: Paulist Press.

Healey, M., Flint, A. and Harrington, K. (2014) Engagement through partnership: students as partners in learning and teaching in higher education. York: Higher Education Academy.

Illeris, K. (Ed) (2009) Contemporary theories of learning. London: Routledge.

Kemmis, S. \& McTaggart, R. (2005). Participatory action research. Communicative action and the public sphere. In Denzin, N. and Lincoln, Y. (Eds.), Handbook of qualitative research (3rd ed.). Thousand Oaks, CA: Sage. pp 559-603.

Light, G., Cox, R. \& Calkins, S. (2009) Learning and teaching in Higher Education: The reflective professional. 2nd Edition. London: Sage.

Morris, D. and Martin, S. (2009) 'Complexity, systems thinking and practice', in A. Stibbe (ed.) The Handbook of Sustainability Literacy. Dartington: Green Books. pp 156-164.

Peterson, A. \& Warwick, P. (2014) Global Learning and Education. Oxon: Routledge.

Pring, R. (2000) Philosophy of educational research. London: Continuum.

Puchner, L. \& Taylor, A. (2006) 'Lesson study, collaboration and teacher efficacy: Stories from two school-based Math Lesson Study Groups.' Teaching and Teacher Education 22 (7): 922-934

Quality Assurance Agency for Higher Education (QAA) (2014) Education for sustainable development: Guidance for UK higher education providers. Gloucester: QAA.

Robinson, K. (2011) Out of Our Minds: Learning to be Creative. Chichester: Capstone.

Stanton, T., Giles, D. and Cruz, N. (1990) Service-Learning. San Francisco: JosseyBass

Sterling, S. (2015) The Centre for Sustainable Futures: A Ten Year Journey.

Warwick, P. (Ed) (2015) Marking ten years of the Centre for Sustainable Futures:

Sustainable Education in Motion. Plymouth: Plymouth University. pp 3-4

Sterling, S (2012) The Future Fit Framework - An introductory guide to teaching and learning for sustainability in HE, The Higher Education Academy, York. 
https://www.heacademy.ac.uk/node/3573

Sterling, S. (2005) Linking Thinking: New Perspectives on Thinking and Learning for Sustainability. Dunkeld: WWF Scotland.

Sterling, S, Maxey, L, and Luna, H, (2013) The Sustainable University - progress and prospects, Routledge/Earthscan, Abingdon.

Stone, M. (2009) Smart by Nature: Schooling for Sustainability. Healdsburg, CA: Watershed Media.

Stone, M. and Barlow, Z. (eds) (2005) Ecological Literacy Educating Our Children for a Sustainable World. San Francisco, CA: Sierra Club Books.

Tilbury, D. (2011) Education for Sustainable Development: An Expert Review of Processes and Learning. Paris: UNESCO.

United Nations Economic Commission for Europe (UNECE) (2012) Learning for the future: Competencies in Education for Sustainable Development. Paris: UNECE.

Vare, P. and Scott, W. (2007) 'Learning for a change: exploring the relationship between education and sustainable development', in Journal of Education for Sustainable Development. 1 (2). 191-98.

Wayman, S. (2009) 'Futures thinking' in A. Stibbe (ed.) The Handbook of Sustainability Literacy. Dartington: Green Books. pp 94-98

Wood, P., Warwick, P. \& Cox, D. (2012) 'Developing learning spaces in higher education: An evaluation of experimental spaces at the University of Leicester' Learning and Teaching. Vol 5. No 2 Summer 2012 pp49-72 